\title{
PENGARUH PERUBAHAN IGNITION TIMING TERHADAP KINERJA MESIN SEPEDA MOTOR AUTOMATIC 115CC
}

\author{
Ragil Sukarno, Darwin Rio Budi Syaka, Adhitya Randa Asier \\ Program Studi Pendidikan Teknik Mesin, Fakultas Teknik - Universitas \\ Negeri Jakarta \\ Email : ragil-sukarno@unj.ac.id
}

\begin{abstract}
ABSTRAK
Penelitian ini bertujuan untuk melihat pengaruh perubahan waktu pengapian (ignition timing) terhadap kinerja mesin dalam bentuk daya dan torsi dan konsumsi bahan bakar dengan menggunakan ECU programmable yang diterapkan pada mesin sepeda motor Automatic 115cc. Pengujian daya dan torsi dilakukan dengan menggunakan dinamometer terhadap sepeda motor dengan 5 variasi waktu pengapian, yaitu waktu pengapian standar (150 Sebelum TMA), 17,5 sebelum TMA, $20^{\circ}$ sebelum TMA, 22,5 sebelum TMA dan $25^{\circ}$ sebelum TMA. Pengujian konsmusi bahan bakar juga dilakukan terhadap sepeda motor pada tiap-tiap variasi waktu pengapian. Dari hasil pengujian didapatkan bahwa perubahan waktu pengapian dapat menaikkan kinerja mesin dan menurunkan konsumsi bahan bakar. Waktu pengapian terbaik terjadi pada 17,50 sebelum TMA yang menghasilkan torsi sebesar 14,36 N.m atau mengalami kenaikan 12,5\% dari torsi mesin waktu pengapian standar dan daya mesin sebesar 8,6 HP atau mengalami peningkatan sebesar $13,9 \%$ dari daya mesin pada waktu pengapian standar. Perubahan waktu pengapian ke $17,50^{\circ}$ sebelum TMA juga menurunkan konsumsi bahan bakar menjadi 0,1480 $\mathrm{ml} / \mathrm{s}$ atau mengalami penurunan 28,95\% dari konsumsi bahan bakar pada waktu pengapian standar.
\end{abstract}

Kata Kunci: Waktu Pengapian (ignition timing), kinerja mesin, Engine Control Unit (ECU)

\section{PENDAHULUAN}

Seiring dengan tingkat mobilitas masyarakat dan volume jalan yang sangat padat terutama di daerah perkotaan, sepeda motor menjadi sarana transportasi alternatif yang dipilih masyarakat dalam berkendara. Selain penghematan biaya, hal ini dimaksudkan untuk lebih fleksibel dalam mengatasi masalah kemacetan lalu lintas di jalan raya.

Dalam menggunakan sepeda motor, kinerja sepeda motor dalam bentuk daya dan torsi yang memadai sangat dibutuhkan sehingga kenyamanan berkendara bisa didapatkan. Namun ukuran kinerja mesin dari suatu kendaraan tidak hanya dilihat dari torsi dan daya maksimum saja, tetapi konsumsi bahan bakar dari sepeda motor tersebut juga patut diperhitungkan. Sehingga sebuah penemuan atau teknologi baru diperlukan untuk meningkatkan daya dan torsi mesin serta konsumsi bahan bakar yang rendah. Salah satu faktor yang mempengaruhi daya, torsi dan konsumsi bahan bakar kendaraan adalah kesempurnaan proses pembakaran di ruang bakar.

Seiring peningkatan pengetahuan dibidang otomotif dan keinginan untuk meningkatkan kinerja sepeda motor yang lebih baik dari kondisi standar maka membuat pengguna sepeda motor melakukan modifikasi sepeda motornya. Dalam upaya meningkatkan daya, torsi dan efiensi bahan bakar, usaha yang sering dilakukan oleh para pemodifikasi adalah dengan cara mengganti komponen, merubah sistem masukan dan pembuangan bahan bakar, dan sistem pengapian.

Dalam sistem pengapian, megubah pick-up sensor merupakan cara yang paling mudah dan efektif untuk menaikkan kinerja mesin. Pick-up sensor merupakan bagian yang sangat penting dalam sistem pengapian CDI yaitu bagian dari magnet yang mengatur waktu pengapian dan lamanya pengapian pada sepeda motor. Apabila pickup sensor terlalu pendek maka pengapian yang terjadi menjadi terlalu singkat. Dan ini 
akan berpengaruh terhadap proses pembakaran yang kurang sempurna. Sedangkan bila pick-up sensor terlalu panjang maka proses pengapian yang terjadi menjadi terlalu lama. Proses pengapian yang lama akan membuat pembakaran terjadi secara sempurna namun bisa mengakibatkan kerusakan komponen yang lain seperti CDI/ECU dan busi.

Pada saat ini hampir semua motor terbaru sudah menggunakan sistem injeksi, khususnya untuk motor automatic. Sebagian pengguna motor automatic merasakan adanya penurunan kinerja pada motor setelah digunakan sekian lama terutama dari segi responsifitas. Banyak cara yang bisa dilakukan untuk meningkatkan kinerja mesin motor injeksi automatic, namun kenaikan kinerja dalam bentuk daya dan torsi tersebut juga mengakibatkan kenaikan konsumsi bahan bakar bila dibandingkan dari standarnya. Berdasarkan hal tersebut, maka dalam penelitian ini akan dilakukan metode baru untuk meningkatkan kinerja mesin namun konsumsi bahan bakar tetap rendah. Berdasarkan dengan hal tersebut, dalam penelitian ini akan dianalisa bagaimana pengaruh waktu pengapian (ignition timing)terhadap daya, torsi dan konsumsi bahan bakar pada sepeda motor Matic $115 \mathrm{cc}$ jika sudut pengapian diubah dengan ECU programmable.

\section{TUJUAN PENELITIAN}

Tujuan dari penelitian ini adalah untuk mengetahui waktu pengapian terbaik untuk mendapatkan kinerja mesin dan konsumsi bahan bakar yang optimal. Selain itu juga untuk melihat bagaimana pengaruh penggunaan penggunaan ECU programmable pada sepeda motor automatic $115 \mathrm{cc}$ terhadap kinerja mesin dan konsumsi bahan bakar.

\section{TINJAUAN PUSTAKA}

\subsection{Sistem Pengapian}

Pada mesin pembakaran dalam, proses pembakaran campuran udara dan bahan bakar terjadi didalam silinder sehingga bisa menghasilkan tenaga. Pada motor bensin dibutuhkan sebuah sistem pengapian yang menyediakan percikan bunga api tegangan tinggi dari busi untuk menyalakan campuran udara dan bahan bakar yang telah dimampatkan oleh torak didalam silinder.

Untuk menghasilkan proses pembakaran yang sempurna, maka proses penyalaan harus terjadi pada saat yang tepat, sehingga pada sistem penyalaan ini terdapat proses yang dinamakan Waktu pengapian (ignition timing). Waktu pengapian (ignition timing) merupakan proses pengaturan waktu pengapian dimana percikan api tegangan tinggi dari busi yang terjadi di dalam ruang bakar ditentukan oleh sudut poros engkol dan posisi torak.

Posisi pengapian diukur dalam derajat perputaran poros engkol, yaitu sebelum atau sesudah TMA pada saat langkah kompresi. Penentuan ignition timing yang tepat merupakan faktor yang sangat penting untuk mendapatkan kinerja motor yang optimal.

Jika waktu pengapian (ignition timing) terlalu maju (sebelum TMA), maka proses pengapian dan ekspansi gas pembakaran di dalam silinder juga akan terjadi dengan lebih cepat dan tekanan gas pembakaran akan meningkat dengan cepat. Kondisi ini akan mendorong torak kebawah meskipun proses kompresi masih berlangsung. Selain itu gas sisa yang belum terbakar akan terbakar dengan sendirinya sehingga menyebabkan terjadinya detonasi atau kerugian daya.

Jika waktu pengapian (ignition timing) terlalu lambat setelah melewati TMA, maka torak telah melewati TMA dan mulai bergerak kebawah ketika bahan bakar sedang dinyalakan. Pada kondisi ini sebagian besar proses pembakaran terjadi pada saat torak sudah bergerak dari TMA ke TMB. Pada kondisi tersebut tekanan gas silinder maksimum akan terjadi pada saat torak sudah berada pada posisi yang lebih jauh dari posisi TMA. Sehingga ini akan mengakibatkan kinerja motor menjadi lemah, emisi buang tinggi, kehilangan daya, dan masih ada bahan bakar yang tidak terbakar. Pengapian yang tepat adalah kondisi dimana proses pembakaran berakhir di sekitar TMA.

\subsection{Torsi Mesin}

Torsi merupakan suatu ukuran kemampuan motor dalam menghasilkan kerja. Pada sebuah motor bakar, torsi ditunjukkan oleh momen sebagai output dari poros engkol. Dalam pengoperasiaanya, torsi motor dibutuhkan pada waktu kendaraan 
akan bergerak atau pada saaat mempercepat laju kendaraan, dan tenaga berguna untuk memperoleh kecepatan tinggi. Proses pembakaran yang sempurna pada sebuah motor bakar akan memberikan dampak positif terhadap torsi mesin yang dihasilkan. Pada sebuah mesin yang beroperasi akan menghasilkan gaya pada torak sebagai hasil dari tekanan hasil pembakaran (F) dan jarijari lingkar poros engkol ( $r$ ), sehingga besarnya torsi dapat ditentukan dari persamaan :

$$
\mathrm{T}=\mathrm{F} . \mathrm{r}
$$

Dimana :

$\mathrm{T}=$ Torsi keluaran mesin (N.m)

$\mathrm{F}=$ Gaya $(\mathrm{N})$

$\mathrm{r}=$ jari - jari lingkar poros engkol (m)

\subsection{Daya Mesin}

Daya mesin pada sebuah motor bakar didefinisikan sebagai besarnya kerja yang dihasilkan oleh poros penggerak atau besarnya laju kerja yang dilakukan. Semakin besar kemampuan operasi mesin tersebut, maka bisa dikatakan bahwa mesin tersebut memiliki daya yang semakin besar. Daya mesin dinyatakan dengan persamaan sebagai berikut

$$
\begin{aligned}
& P=\frac{2 \pi n T}{60.000} \ldots \ldots(k W) \\
& \text { Dimana }: \\
& \mathrm{T}=\text { Torsi keluaran mesin }(\mathrm{Nm}) \\
& \mathrm{n}=\text { putaran mesin }(\mathrm{rpm})
\end{aligned}
$$

Daya juga bisa dinyatakan dalam satuan HP ( horse power). Jika diketahui torsi (T) dalam lbf.ft, maka besarnya daya mesin ditunjukkan dengan persamaan berikut :

$$
P=\frac{T \cdot n}{5252} \ldots \ldots(H P)
$$

$\mathrm{P}=$ Daya keluaran mesin (HP)

$\mathrm{T}=$ Torsi keluaran Mesin ( lbf.ft)

$\mathrm{n}=$ putaran mesin (rpm)

\section{METODE PENELITIAN}

Langkah-langkah yang dilakukan dalam melaksanakan penelitian ini bisa ditunjukkan pada gambar berikut ini.

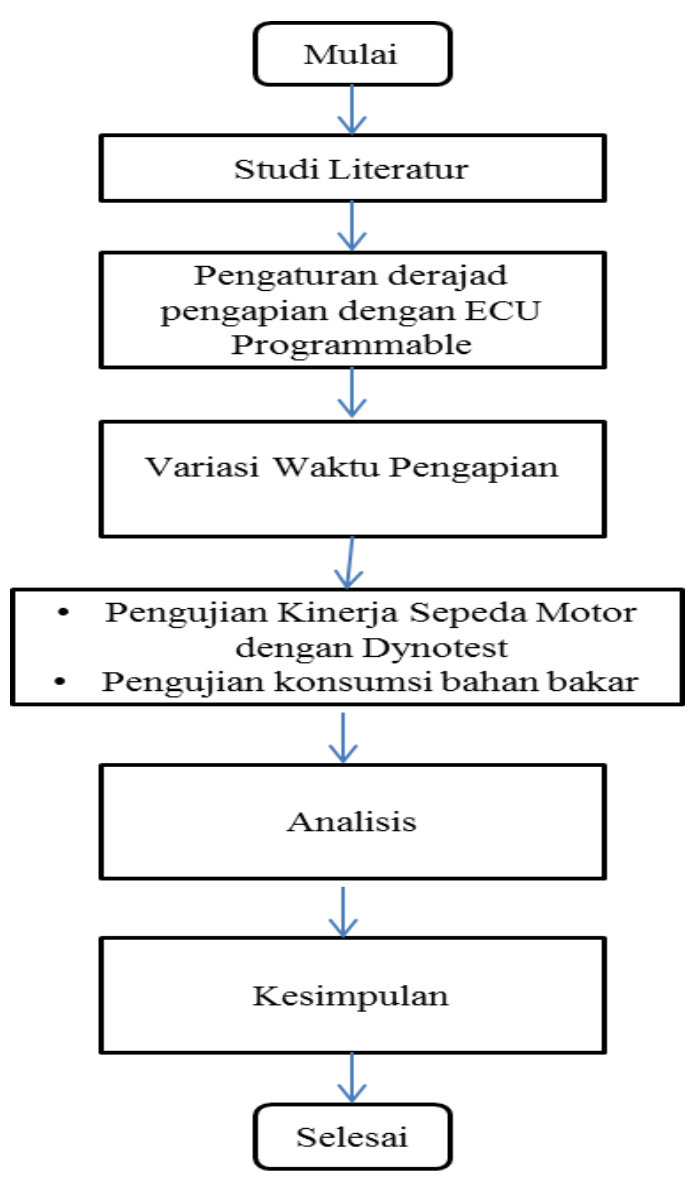

Gambar 1. Diagram Alir Metode Penelitian

Pada penelitian ini diuji pengaruh variasi waktu pengapian terhadap daya dan torsi mesin serta konsumsi bahan bakar dengan menggunakan ECU programmable “ECU BRT Juken 3" yang diterapkan pada mesin sepeda motor Yamaha GT Automatic $115 \mathrm{cc}$.

Variasi waktu pengapian yang akan diuji adalah pengapian standar yaitu $15^{\circ}$ sebelum TMA dan selanjutnya menambahkan setiap $+2,5^{\circ}$ dengan 5 variasi waktu pengapian.

Berturut-turut variasi waktu pengapian adalah $15^{\circ}$ sebelum TMA, $17,5^{\circ}$ sebelum TMA, $20^{\circ}$ sebelum TMA, 22,5 $5^{\circ}$ sebelum 
TMA dan $25^{\circ}$ sebelum TMA). Busi yang digunakan pada pengujian adalah busi NGK, dan bahan bakar yang digunakan adalah pertamax 92 .

Untuk mendapatkan daya dan torsi dilakukan pengujian dengan menggunakan dynamometer (dyno test). Pengujian terhadap masing-masing waktu pengapian dilakukan 3 kali agar didapatkan hasil yang optimal. ECU juken 3 di aplikasikan pada motor yang telah di program dengan komputer untuk menghasilkan wakyu pengapian. Bersamaan dengan itu dipasangkan remote ECU untuk memantau AFR yang dihasilkan.

Pengujian konsusi bahan bakar dilakukan dengan cara mengukur waktu yang dibutuhkan oleh mesin untuk menghabiskan $65 \mathrm{ml}$ bahan bakar pada tiaptiap variasi waktu pengapian. Pada saat pengujian mesin dihidupkan kondisi putaran RPM 4000 sampai mesin menghabiskan seluruh bahan bakar tersebut.

Sepeda motor yang digunakan pada penelitian ini menggunakan sepeda motor Yamaha GT Automatic 115 cc. Sepeda motor yang digunakan tidak ada perubahan apapun, hanya mengganti ECU programmable untuk mengatur derajat pengapian dengan beberapa 5 variasi yang berbeda. Sebelum melakukan pengujian dynotest, sepeda motor diservis terlebih dahulu dan diposisikan dalam keadaan standar untuk mendapatkan kondisi yang optimal saat dilakukan pengujian dinamometer.

Penyetelan dan Prosedur Pengujian dengan menggunakan dynamometer ditunjukkan pada gambar 2 .

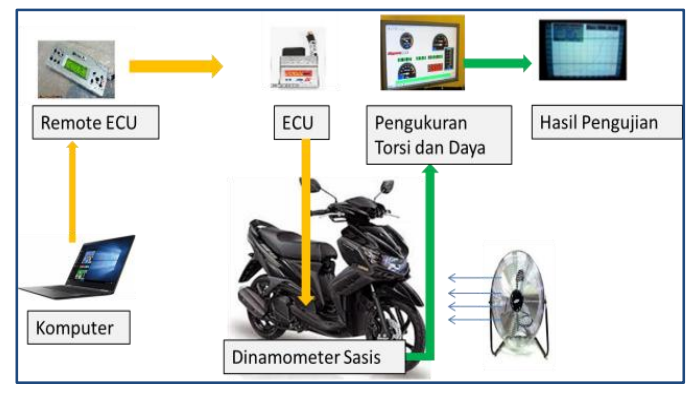

Gambar 2. Proses Pengujian Daya dan Torsi
Sedangkan proses pengujian konsumsi bahan bakar ditunjukkan pada gambar 3 .

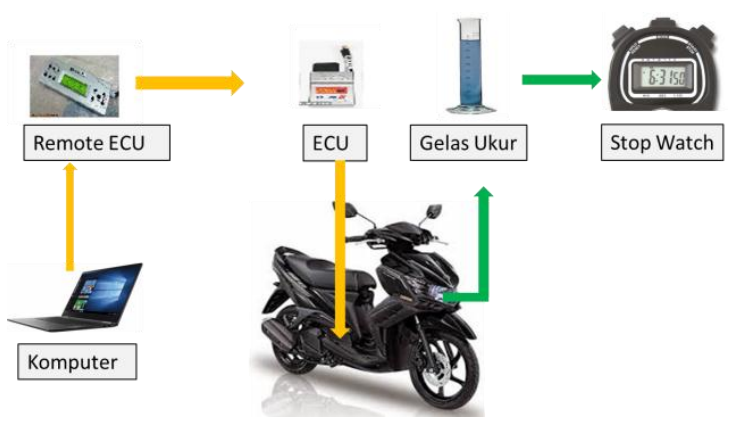

Gambar 3. Proses Pengukuran konsumsi bahan bakar

\section{HASIL DAN PEMBAHASAN}

\subsection{Hasil Pengujian Torsi Mesin}

Hasil pengujian torsi mesin dengan menggunakan dynotest diperlihatkan pada gambar 4 berikut ini.

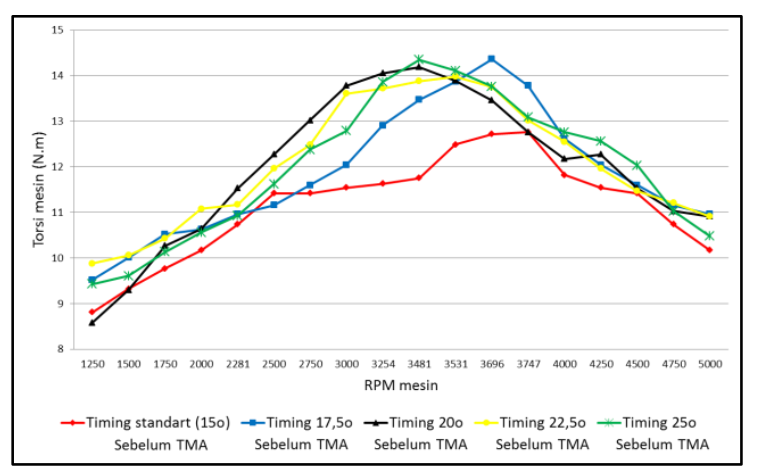

Gambar 4. Grafik Torsi - Putaran Mesin

Dari grafik torsi mesin pada gambar 4, menunjukan bahwa pengujian dari kelima variasi waktu pengapian adalah sebagai berikut:

- waktu pengapian standard $\left(15^{\circ}\right.$ sebelum TMA) menghasilkan torsi tertinggi sebesar 12.76 N.m pada RPM 3747.

- waktu pengapian $17,5^{\circ}$ sebelum TMA menghasilkan torsi tertinggi sebesar 14.36 N.m pada RPM 3696. 
- waktu pengapian $20^{\circ}$ sebelum TMA menghasilkan torsi tertinggi sebesar 14.19 N.m pada RPM 3481.

- waktu pengapian $22,5^{\circ}$ sebelum TMA menghasilkan torsi tertinggi sebesar 13.98 N.m pada RPM 3531.

- waktu pengapian $25^{\circ}$ sebelum TMA menghasilkan torsi tertinggi sebesar 14.35 N.m pada RPM 3518.

Berdasarkan hasil pengujian, waktu pengapian yang menghasilkan torsi terbaik adalah timing waktu $17,5^{\circ}$ sebelum TMA dengan torsi sebesar 14,36 N.m.atau mengalami kenaikan $12,5 \%$ dari torsi mesin waktu pengapian standar.

\subsection{Hasil Pengujian Daya Mesin}

Hasil pengujian daya mesin dengan menggunakan dynotest diperlihatkan pada gambar 5 .

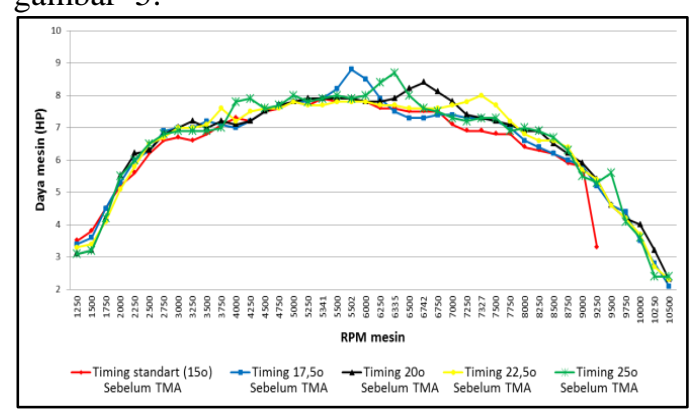

Gambar 5. Grafik Daya - Putaran Mesin

Dari grafik daya mesin pada gambar 5, menunjukan bahwa pengujian dari kelima variasi waktu pengapian adalah sebagai berikut:

- Waktu pengapian standard ( $15^{\circ}$ sebelum TMA ) menghasilkan daya tertinggi sebesar 7.9 HP pada RPM 5341.

- Waktu pengapian $17,5^{\circ}$ sebelum TMA menghasilkan daya tertinggi sebesar 8.6 HP pada RPM 5502.

- Waktu pengapian $20^{\circ}$ sebelum TMA menghasilkan daya tertinggi sebesar 8.2 HP pada RPM 6742.
- Waktu pengapian $22,5^{\circ}$ sebelum TMA menghasilkan daya tertinggi sebesar 8.7 HP pada RPM 6335.

- Waktu pengapian $25^{\circ}$ sebelum TMA menghasilkan daya tertinggi sebesar 8.0 HP pada RPM 7327.

\subsection{Hasil Pengujian Konsumsi Bahan Bakar}

Hasil pengujian konsumsi bahan bakar untuk 5 variasi waktu pengapian ditunjukkan pada gambar 6 .

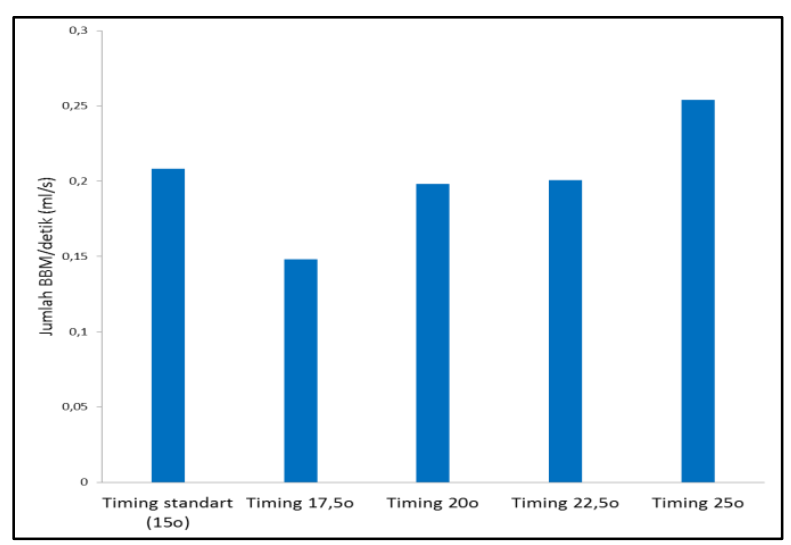

Gambar 6. Hasil Pengujian Konsumsi Bahan Bakar

Dari grafik konsumsi bahan bakar mesin menunjukan bahwa pengujian dari kelima variasi timing pengapian adalah sebagai berikut:

- Waktu pengapian standard ( $15^{\circ}$ sebelum TMA) menghasilkan konsumsi bahan bakar sebesar 0.2083 $\mathrm{ml} / \mathrm{s}$

- Waktu pengapian $17,5^{\circ}$ sebelum TMA menghasilkan konsumsi bahan bakar sebesar $0.1480 \mathrm{ml} / \mathrm{s}$

- Waktu pengapian $20^{\circ}$ sebelum TMA menghasilkan konsumsi bahan bakar sebesar $0.1981 \mathrm{ml} / \mathrm{s}$

- Waktu pengapian $22,5^{\circ}$ sebelum TMA menghasilkan konsumsi bahan bakar sebesar $0.2006 \mathrm{ml} / \mathrm{s}$. 
- Waktu pengapian $25^{\circ}$ sebelum TMA menghasilkan konsumsi bahan bakar sebesar $0.2539 \mathrm{ml} / \mathrm{s}$.

Berdasarkan hasil pengujian, waktu pengapian dengan konsumsi bahan bakar terbaik adalah $17,5^{\circ}$ sebelum TMA, yaitu sebesar $0.1480 \mathrm{ml} / \mathrm{s}$ atau turun $28,95 \%$ dari konsumsi bahan bakar pada waktu pengapian standar.

\section{KESIMPULAN}

Berdasarkan hasil analisa dan pembahasan pada bab sebelumnya dapat disimpulkan sebagai berikut :

1. Perubahan variasi waktu pengapian (ignition timing) dapat menaikkan kinerja mesin dalam bentuk daya dan torsi dan menurunkan konsumsi bahan bakar.

2. Dari hasil pengujian 5 variasi waktu pengapian, didapatkan bahwa waktu pengapian $17,5^{\circ}$ sebelum TMA merupakan waktu pengapian terbaik dengan menghasilkan daya dan torsi mesin paling tinggi serta tingkat konsumsi bahan bakar paling rendah dibandingkan yang lainnya.

3. Waktu pengapian terbaik terjadi pada $17,50^{\circ}$ sebelum TMA yang menghasilkan torsi sebesar 14,36 N.m atau mengalami kenaikan $12,5 \%$ dari torsi mesin waktu pengapian standar dan daya mesin sebesar 8,6 HP atau mengalami peningkatan sebesar $13,9 \%$ dari daya mesin pada waktu pengapian standar.

4. Perubahan waktu pengapian ke $17,50^{\circ}$ sebelum TMA juga menurunkan konsumsi bahan bakar menjadi 0,1480 $\mathrm{ml} / \mathrm{s}$ atau turun $28,95 \%$ dari konsumsi bahan bakar pada waktu pengapian standar.

5. Berdasarkan hasil pengujian menunjukkan bahwa penggunaan ECU programmable pada sepeda motor sangat berpengaruh terhadap kinerja mesin terlihat adanya peningkatan torsi dan daya yang cukup signifikan serta menurunnya tingkat konsumsi bahan bakar.

\section{DAFTAR PUSTAKA}

- Arismunandar, Wiranto. Motor Bakar Torak. Bandung: ITB. 1994.

- BPM. Arends., H. Berenschot. Motor Bensin. Jakarta : Erlangga. 1992.

- Manual Book. ECU BRT Juken. Cibinong: PT Bintang Racing Team. 2014

- Obert, Edward F. Internal Combustion Engine and Air Pollution. 1973.

- Pratam, Rizki Yoga Nur. Pengaruh Penggunaan Bahan Bakar Pertamax Dan Waktu Pengapian (Ignition Timing) Terhadap Performa Mesin Dan Emisi Gas Buang Sepeda Motor Supra X $125 c c$ Tahun 2008. Universitas Negeri Surabaya. 2014.

- Sugiarto Bambang, dkk. Analisa Kinerja Mesin Otto Berbahan Bakar Premium Dengan Penambahan Aditif Oksigenat Dan Aditif Pasaran. Universitas Indonesia. 2007.

- Ir. Philip Kristanto, Motor Bakar Torak "Teori dan Aplikasinya”, Penerbit Andi, Yogyakarta, 2015

- Dan Sumber Lain Yang Relevan 